\title{
Effect of Different Levels of NPK and FYM on Physico-Chemical Properties of Soil of Okra [Abelmoschus esculentus L.] Var. Parbhani Kranti
}

\author{
Radhakishan Yadav*, Tarence Thomas and Narendra Swaroop \\ Department of Soil Science and Agricultural Chemistry, [Naini Agricultural Institute], \\ Sam Higginbottom University of Agriculture, Technology and Sciences, \\ Prayagraj - 211007, U.P., India \\ *Corresponding author
}

\begin{tabular}{l} 
Ke y w o r d s \\
$\begin{array}{l}\text { Okra, NPK and } \\
\text { FYM, Physico- } \\
\text { chemical Properties } \\
\text { of Soil etc }\end{array}$ \\
Article Info \\
$\begin{array}{l}\text { Accepted: } \\
\text { 10 July } 2020 \\
\text { Available Online: } \\
\text { 10 August } 2020\end{array}$ \\
\hline
\end{tabular}

A B S T R A C T

\begin{abstract}
The field experiment was conducted during kharif (rainy) season of 2019 on "Effect of different levels of NPK and FYM on physico-chemical properties of soil of Okra (Abelmoschus esculntus L.) var. Parbhani Karanti” on Central Research Farm Department of Soil Science and Agricultural Chemistry, SHUATS, Prayagraj. The soil of experiment area falls in order Inceptisol and soil texture was sandy loam (sand \% 61.20, silt \% 23.20 and clay \% 14.6). There were 9 treatments combination replicated thrice in $3 \times 3$ factorial randomized block design. It was observed that for post harvest, soil properties in treatment $\mathrm{T}_{8^{-}}\left(100 \% \mathrm{RDF} @ \mathrm{~N}_{100} \mathrm{P}_{60} \mathrm{~K}_{50}\right.$ $\mathrm{kg} \mathrm{ha}^{-1}+100 \%$ FYM @ $25 \mathrm{t} \mathrm{ha}^{-1}$ ) were improved significantly due to organic and inorganic use of inputs. The maximum values of pore space $(60.1 \%)$, water holding capacity $(63.63 \%)$, organic carbon $(0.62 \%)$, available nitrogen $\left(297.56 \mathrm{~kg} \mathrm{ha}^{-1}\right)$, available phosphorus $(26.35 \mathrm{~kg}$ $\left.\mathrm{ha}^{-1}\right)$ and available potassium $\left(202.55 \mathrm{~kg} \mathrm{ha}^{-1}\right)$ was with treatment $\mathrm{T}_{8^{-}}\left(100 \% \mathrm{RDF} @ \mathrm{~N}_{100} \mathrm{P}_{60}\right.$ $\left.\mathrm{K}_{50} \mathrm{~kg} \mathrm{ha}^{-1}+100 \% \mathrm{FYM} @ 25 \mathrm{t} \mathrm{ha}^{-1}\right)$. The combination of $\mathrm{T}_{8^{-}}\left(100 \% \mathrm{RDF} @ \mathrm{~N}_{100} \mathrm{P}_{60} \mathrm{~K}_{50} \mathrm{~kg} \mathrm{ha}^{-}\right.$ ${ }^{1}+100 \%$ FYM @ $25 \mathrm{t} \mathrm{ha}^{-1}$ ) showed slight decrease in $\mathrm{pH}(6.8)$, bulk density $\left(1.18 \mathrm{Mg} \mathrm{m}^{-3}\right)$ and particle density $\left(2.50 \mathrm{Mg} \mathrm{m}^{-3}\right)$, the same treatment EC $\left(0.33 \mathrm{dS} \mathrm{m}^{-1}\right)$ was slightly increase in post harvest soil. It may be concluded from trial that the various level of NPK and FYM used from different sources in the experiment, the treatment $\mathrm{T}_{8}-\left(100 \% \mathrm{RDF} @ \mathrm{~N}_{100} \mathrm{P}_{60} \mathrm{~K}_{50} \mathrm{~kg} \mathrm{ha}{ }^{-1}\right.$ $+100 \%$ FYM @ $25 \mathrm{t} \mathrm{ha}^{-1}$ ) was found to be the best, for improvement in physical and chemical properties of soil.
\end{abstract}

\section{Introduction}

Okra [Abelmoschus esculentus L.] is an important fruit vegetable crop cultivated in tropical, subtropical and mild temperate parts of the world and belongs to the family Malvaceae. In India, it is grown during summer and rainy seasons for its tender pod, which are cooked and consumed as a vegetable (Chattopadhyay et al., 2011). Okra
(Abelmoschus esculentus L.) originated in Ethiopia (Sathish \& Eswar, 2013). Okra (Abelmoschus esculentus) is one of the most widely known and utilized species of the family Malvaceae (Naveed et al., 2009). Okra is most popular in India, Nigeria, Sudan, Pakistan, Ghana, Egypt, Benin, Saudi Arabia, Mexico and Cameroon. Largest area and production is in India followed by Nigeria. Total area under okra in India is reported to 
be 528.37 thousand hectare, production 6145.97 thousand tonnes and productivity $11.5 \mathrm{t} \mathrm{ha}^{-1}$ in 2018-19. West Bengal is the leading state of area and production of okra, which has area 77.40 thousand hectare and production 913.32 thousand tonnes. Highest productivity is $17.40 \mathrm{t} \mathrm{ha}^{-1}$ of Andhra Pradesh. Uttar Pradesh climate is good for okra that in total area 22.64 thousand hectare and production is 303.05 thousand tonnes in 201819 (NHB data base 2018-19).

Total area under okra in World is reported to be 2020528 hectare and production 9872826 tonnes in 2018. Okra is valued for its edible green pods (fruits), a capsule that contains many seeds. However, its leaves are also eaten as a vegetable. Okra seeds are used as a non-caffeinated substitute for coffee and also as a source of seed oil (FAO, 2018). Okra is said to be of economic importance because of its nutritional value that has the potential to improve food security (FAO, 2018). The significance of crop further enhances due to its multiple uses. The dry seed contains 13-22 percent good quality edible oil and 20-24 per cent protein. The green fruits contain water $88.6 \mathrm{~g}$, energy $36 \mathrm{kcal}$, protein $2.1 \mathrm{~g}$, carbohydrate $8.2 \mathrm{~g}$, fat $0.2 \mathrm{~g}$, fiber $1.7 \mathrm{~g}, \mathrm{Ca} 84$ $\mathrm{mg}$, P $90 \mathrm{mg}$, Fe $1.2 \mathrm{mg}$, beta carotene 185 micro gram, riboflavin $0.08 \mathrm{mg}$, thiamin 0.04 $\mathrm{mg}$, niacin $0.6 \mathrm{mg}$ and ascorbic acid $47 \mathrm{mg}$ per $100 \mathrm{~g}$ edible portion (Habtamu et al., 2014). Fresh pods also contain about $30 \%$ of recommended levels of vitamin C (16-29 $\mathrm{mg}$ ), $10-20 \%$ of folate (46-88 mg) and about $5 \%$ of vitamin A (14-20 RAE) (Gemede et al., 2014).

The main challenge before India is to increase the production of quality food in a sustainable manner and feeding the country's large population and increasing the income of the farmer. The requirements of fertilizers in okra are important for the early growth and total production of fruit yield. Use of organic and inorganic fertilizers can improve crop productivity (Mal et al., 2013). Organic fertilizer released all type of micro and macro nutrients that helps to plant elongation. Organic fertilizers improved soil physical properties and supplied of essential plant nutrients for higher growth of plant, protect soil against erosion, supply the cementing substance for desirable aggregate soil formation and loosen the soil. Application of FYM sustains cropping system through better nutrient recycling and provides all necessary nutrients, thereby improving the physical and biological properties of soil (Abou El-Magd et al., 2006).

The effects of fertilizer on the growth and yield of okra had been reported in various studies (Agbede and AAdekiya, 2012), (Uka et al., 2013). In the experiment conducted by (Firoz et al., 2009) on the relative effects of inorganic and organic fertilizer on the growth of okra, it was observed that both fertilizer types produced significantly higher value for plant height, fresh weight, leaf area and dry weight compared to the control without fertilizer.

Nitrogen plays a major role among cultural practices for increased crop production. However, blanket application of inorganic fertilizer to farmland soils without adequate knowledge of the nutrient status, often leads to increased soil acidity, particularly when nitrogen fertilizers are applied (Akande et al., 2010).

Phosphorus can influence fruiting and fruit developments of crops and regarded as key of life because it is directly involved in most living process. Phosphorus is a key constituent of ATP which transforms energy to the plant. Phosphorus take part in various physiological process and helps in nutrients uptake by promoting root growth and their by ensuring a good pod yield (Das et al., 2014). 
Potassium plays a unique role in osmotic regulation, opening and closing of stomata and improves the color, flavours and size of fruits (Bhende et al., 2015).

Application of FYM and poultry manure or in combination with chemical fertilizers improved the soil organic C, total NPK status. However, only organic manure or combined applications of organic manure with inorganic fertilizers increase soil microbial growth (Kaur et al., 2005). The organic manure FYM not only provides nutrient to the plant but also improves the soil texture by binding effect of soil aggregates. Organic manure increases cation exchange capacity, water holding capacity and phosphate availability of the soil beside improving the fertilizer use efficiency and microbial population of soil, it reduces nitrogen loses due to slow release of nutrients (Tadesse et al., 2013). FYM plus inorganic NPK applications in irrigated systems resulted in reduced bulk density, higher soil organic carbon and hydraulic conductivity and improved soil structure and microbial communities (Bhattacharya et al., 2007).

\section{Materials and Methods}

The investigation on Effect of Different Levels of NPK and FYM on Growth and Yield of Okra [Abelmoschus esculentus L.] var. Parbhani Karanti comprise of a field experiment which was carried out at the Soil Science Research Farm, Sam Higginbottom University of Agriculture, Technology and Science, Prayagraj during kharif season on $22^{\text {th }}$ July to $18^{\text {th }}$ October (2019-20).

The area is situated on the South of Prayagraj on the right side of the river Yamuna on the South of Rewa Road at a distance of about 6 $\mathrm{Km}$ from Prayagraj city. It is situated at 25024'23”N latitude, 81050'38'E longitude and at the altitude of 98 meter above the sea level. The maximum temperature of the location reaches up to $460 \mathrm{C}-480 \mathrm{C}$ and seldom falls as low as 40C - 50C. The relative humidity ranged between 20 to 94 percent. The average rainfall in this area is around $1100 \mathrm{~mm}$ annually.

The Experiment was laid out in a $3 \times 3$ Factorial Randomized Block Design (FRBD) (Fisher R. A. 1958) with 9 treatments and 3 replications. The treatment consisted of all combination, 3 levels of NPK fertilizer 0\% @ $\mathrm{N}_{0} \mathrm{P}_{0} \mathrm{~K}_{0} \mathrm{~kg} \mathrm{ha}^{-1}, 50 \% @ \mathrm{~N}_{50} \mathrm{P}_{30} \mathrm{~K}_{25} \mathrm{~kg} \mathrm{ha}^{-1}$ and $100 \% @ \mathrm{~N}_{100} \mathrm{P}_{60} \mathrm{~K}_{50} \mathrm{~kg} \mathrm{ha}^{-1}$ and 3 levels of FYM 0\%, 50\% and 100\% @ $0 \mathrm{t} \mathrm{ha}^{-1}, 12.5 \mathrm{t}$ $\mathrm{ha}^{-1}$ and $25 \mathrm{t} \mathrm{ha}^{-1}$. The recommended dose of fertilizers i.e. nitrogen, phosphrous and potassium (100\%)and FYM (100\%) was applied in the ratio of 100:60:50 kg ha $\mathrm{kg}^{-1}$ and FYM $25 \mathrm{t} \mathrm{ha}^{-1}$, respectively. The source of nitrogen was through urea $(46 \% \quad \mathrm{~N})$, phosphorus through single super phosphate $\left(16 \% \mathrm{P}_{2} \mathrm{O}_{5}\right)$, potassium through muriate of potash $\left(60 \% \mathrm{~K}_{2} \mathrm{O}\right)$ and FYM $\left(0.5 \% \mathrm{~N}_{2}, 0.2 \%\right.$ $\mathrm{P}_{2} \mathrm{O}_{5}$, and $0.5 \% \mathrm{~K}_{2} \mathrm{O}$ ). Dose of fertilizer was applied in respective plots according to treatment allocation uniform furrows opened by about $5 \mathrm{~cm}$. The plant distance $\mathrm{R} \times \mathrm{R}=45$ $\mathrm{cm}$ and $\mathrm{P} \times \mathrm{P}=30 \mathrm{~cm}$, and seed rate $8-10 \mathrm{~kg}$ $\mathrm{ha}^{-1}$. All the agronomic practices were carried out uniformly to raise the crop.

\section{Results and Discussion}

\section{Bulk density $\left(\mathrm{Mg} \mathrm{m}^{-3}\right)$}

The data presented in shows the Bulk density $\left(\mathrm{Mg} \mathrm{m}^{-3}\right)$ of soil as influenced by $\mathrm{N}$ P K fertilizers and FYM. The response Bulk density $\left(\mathrm{Mg} \mathrm{m}^{-3}\right)$ of soil was found to be nonsignificant in levels of N P K and FYM. The maximum Bulk density $\left(\mathrm{Mg} \mathrm{m}^{-3}\right)$ of soil was recorded $1.31 \mathrm{Mg} \mathrm{m}^{-3}$ in treatment $\mathrm{T}_{0}$ (control) and minimum Bulk density $\left(\mathrm{Mg} \mathrm{m}^{-3}\right)$ of soil was recorded $1.18 \mathrm{Mg} \mathrm{m}^{-3}$ in treatment $\mathrm{T}_{8}\left(100 \% \mathrm{RDF} @ \mathrm{~N}_{100} \mathrm{P}_{60} \mathrm{~K}_{50} \mathrm{~kg} \mathrm{ha}^{-1}+100 \%\right.$ FYM@ $\left.25 \mathrm{t} \mathrm{ha}^{-1}\right)$. Similar results were also 
reported by Yadav et al., (2019) and Ola et al., (2017).

\section{Particle density $\left(\mathrm{Mg} \mathrm{m}^{-3}\right)$}

The data presented in shows the particle density $\left(\mathrm{Mg} \mathrm{m}^{-3}\right)$ of soil as influenced by N P $\mathrm{K}$ fertilizers and FYM. The response particle density $\left(\mathrm{Mg} \mathrm{m}^{-3}\right)$ of soil was found to be nonsignificant in levels of N P K and FYM. The maximum particle density $\left(\mathrm{Mg} \mathrm{m}^{-3}\right)$ of soil was recorded $2.62 \mathrm{Mg} \mathrm{m}^{-3}$ in treatment $\mathrm{T}_{0}$ (control) and minimum particle density $(\mathrm{Mg}$ $\mathrm{m}^{-3}$ ) of soil was recorded $2.50 \mathrm{Mg} \mathrm{m}^{-3}$ in treatment $\mathrm{T}_{8}$ (100\% RDF @ $\mathrm{N}_{100} \mathrm{P}_{60} \mathrm{~K}_{50} \mathrm{~kg}$ $\mathrm{ha}^{-1}+100 \%$ FYM @ $\left.25 \mathrm{t} \mathrm{ha}^{-1}\right)$. Similar results were also reported by Ola et al., (2017).

\section{\% Pore space}

The data presented in shows the \% Pore space of soil as influenced by N P K fertilizers and FYM. The response \% Pore space of soil was found to be significant in levels of N P K and FYM. The maximum \% Pore space of soil was recorded $60.1 \%$ in treatment $\mathrm{T}_{0}$ (control) and minimum $\%$ Pore space of soil was recorded $47.15 \%$ in treatment $\mathrm{T}_{8}(100 \% \mathrm{RDF}$ @ $\mathrm{N}_{100} \mathrm{P}_{60} \mathrm{~K}_{50} \mathrm{~kg} \mathrm{ha}^{-1}+100 \% \mathrm{FYM} @ 25 \mathrm{t}$ $\left.\mathrm{ha}^{-1}\right)$. Similar results were also reported by Lakra et al., (2017) and Salvi et al., (2015).

\section{Water holding capacity \%}

The data presented in shows the water holding capacity \% of soil as influenced by N P K fertilizers and FYM. The response water holding capacity $\%$ of soil was found to be significant in levels of N P K and FYM. The maximum water holding capacity $\%$ of soil was recorded $63.63 \%$ in treatment $\mathrm{T}_{8}(100 \%$ RDF@ $\mathrm{N}_{100} \mathrm{P}_{60} \mathrm{~K}_{50} \mathrm{~kg} \mathrm{ha}^{-1}+100 \%$ FYM @ $25 \mathrm{t} \mathrm{ha}^{-1}$ ) and minimum water holding capacity $\%$ of soil was recorded $45.53 \%$ in treatment $\mathrm{T}_{0}$ (control). Similar results were also reported by Salvi et al. (2015).

\section{pH (1:2) W/V}

The data presented in shows the $\mathrm{pH}$ of soil as influenced by N P K fertilizers and FYM. The response $\mathrm{pH}$ of soil was found to be significant in levels of N P K and FYM. The maximum $\mathrm{pH}$ of soil was recorded in treatment 7.26 $\mathrm{T}_{0}$ (control) and minimum $\mathrm{pH}$ of soil was recorded 6.88 in treatment $\mathrm{T}_{8}$ (100\% RDF @ $\mathrm{N}_{100} \mathrm{P}_{60} \mathrm{~K}_{50} \mathrm{~kg} \mathrm{ha}^{-1}+100 \%$ FYM @ $\left.25 \mathrm{t} \mathrm{ha}^{-1}\right)$.Similar results were also reported by Bhambhu et al., (2016) and Solangi et al., (2015).

\section{$E C\left(d S m^{-1}\right)$}

The data presented in shows the EC $\left(\mathrm{dS} \mathrm{m}^{-1}\right)$ of soil as influenced by N P K fertilizers and FYM. The response EC $\left(\mathrm{dS} \mathrm{m}^{-1}\right)$ of soil was found to be significant in levels of N P K and FYM. The maximum EC $\left(\mathrm{dS} \mathrm{m}^{-1}\right)$ of soil was recorded $0.32 \mathrm{dS} \mathrm{m}^{-1}$ in treatment $\mathrm{T}_{8}(100 \%$ RDF@ $\mathrm{N}_{100} \mathrm{P}_{60} \mathrm{~K}_{50} \mathrm{~kg} \mathrm{ha}^{-1}+100 \% \mathrm{FYM} @$ $\left.25 \mathrm{t} \mathrm{ha}^{-1}\right)$ and minimum EC ( $\left.\mathrm{dS} \mathrm{m} \mathrm{m}^{-1}\right)$ of soil was recorded $0.28 \mathrm{dSm}^{-1}$ in treatment $\mathrm{T}_{0}$ (control). Similar results were also reported by Salvi et al., (2015) and Ray et al., (2005).

\section{Organic carbon $\%$}

The data presented in shows the organic carbon $\%$ in soil as influenced by $\mathrm{N} \mathrm{P} \mathrm{K}$ fertilizers and FYM. The Organic carbon \% in soil increased significantly with the increase in levels of N P K and FYM. The maximum organic carbon $\%$ in soil was recorded $0.62 \%$ in treatment $\mathrm{T}_{8}\left(100 \% \mathrm{RDF} @ \mathrm{~N}_{100} \mathrm{P}_{60} \mathrm{~K}_{50} \mathrm{~kg}\right.$ $\mathrm{ha}^{-1}+100 \%$ FYM @ $25 \mathrm{t} \mathrm{ha}^{-1}$ ) which was significantly higher than any other treatment combination and the minimum organic carbon $\%$ in soil was recorded $0.39 \%$ in treatment $\mathrm{T}_{0}$ (control). Similar results were observed by Salvi et al. (2015) and Lakra et al. (2017). 
Table.1 Treatment combination of different levels of N P K and FYM for okra trial

\begin{tabular}{|l|l|l|}
\hline Treatment & Treatment combination & Symbol \\
\hline $\mathbf{T}_{\mathbf{0}}$ & Control (Absolute control) & $\mathrm{I}_{0}+\mathrm{F}_{0}$ \\
\hline $\mathbf{T}_{\mathbf{1}}$ & $0 \% \mathrm{RDF}+50 \% \mathrm{FYM} @ 12.5 \mathrm{t} \mathrm{ha}^{-1}$ & $\mathrm{I}_{0}+\mathrm{F}_{1}$ \\
\hline $\mathbf{T}_{\mathbf{2}}$ & $0 \% \mathrm{RDF}+100 \% \mathrm{FYM} @ 25 \mathrm{tha}^{-1}$ & $\mathrm{I}_{0}+\mathrm{F}_{2}$ \\
\hline $\mathbf{T}_{\mathbf{3}}$ & $50 \% \mathrm{RDF} @ \mathrm{~N}_{50} \mathrm{P}_{30} \mathrm{~K}_{25} \mathrm{~kg} \mathrm{ha}^{-1}+0 \% \mathrm{FYM} @ 0 \mathrm{tha}^{-1}$ & $\mathrm{I}_{1}+\mathrm{F}_{0}$ \\
\hline $\mathbf{T}_{\mathbf{4}}$ & $50 \% \mathrm{RDF} @ \mathrm{~N}_{50} \mathrm{P}_{30} \mathrm{~K}_{25} \mathrm{~kg} \mathrm{ha}^{-1}+50 \% \mathrm{FYM} @ 12.5 \mathrm{tha}^{-1}$ & $\mathrm{I}_{1}+\mathrm{F}_{1}$ \\
\hline $\mathbf{T}_{\mathbf{5}}$ & $50 \% \mathrm{RDF} @ \mathrm{~N}_{50} \mathrm{P}_{30} \mathrm{~K}_{25} \mathrm{~kg} \mathrm{ha}^{-1}+100 \% \mathrm{FYM} @ 25 \mathrm{tha}^{-1}$ & $\mathrm{I}_{1}+\mathrm{F}_{2}$ \\
\hline $\mathbf{T}_{\mathbf{6}}$ & $100 \% \mathrm{RDF} @ \mathrm{~N}_{100} \mathrm{P}_{60} \mathrm{~K}_{50} \mathrm{~kg} \mathrm{ha}^{-1}+0 \% \mathrm{FYM} @ 0 \mathrm{tha}$ & $\mathrm{I}_{2}+\mathrm{F}_{0}$ \\
\hline $\mathbf{T}_{\mathbf{7}}$ & $100 \% \mathrm{RDF} @ \mathrm{~N}_{100} \mathrm{P}_{60} \mathrm{~K}_{50} \mathrm{~kg} \mathrm{ha}^{-1}+50 \% \mathrm{FYM} @ 12.5 \mathrm{tha}^{-1}$ & $\mathrm{I}_{2}+\mathrm{F}_{1}$ \\
\hline $\mathbf{T}_{\mathbf{8}}$ & $100 \% \mathrm{RDF} @ \mathrm{~N}_{100} \mathrm{P}_{60} \mathrm{~K}_{50} \mathrm{~kg} \mathrm{ha}^{-1}+100 \% \mathrm{FYM} @ 25 \mathrm{tha}^{-1}$ & $\mathrm{I}_{2}+\mathrm{F}_{2}$ \\
\hline
\end{tabular}

Table.2 Physical analysis of soil before sowing of Okra (Abelmoschus esculentus L.)

\begin{tabular}{|c|c|c|}
\hline Particulars & Results & Method employed \\
\hline Sand $(\%)$ & 61.20 & \multirow{4}{*}{ Bouyoucos Hydrometer method (1927) } \\
\hline Silt $(\%)$ & 23.20 & \\
\hline Clay $(\%)$ & 14.6 & \\
\hline Textural class & Sandy loam & \\
\hline Bulk density $\left(\mathrm{Mg} \mathrm{m}^{-3}\right)$ & 1.32 & \\
\hline Particle density $\left(\mathrm{Mg} \mathrm{m}^{-3}\right)$ & 2.61 & \\
\hline Pore Space (\%) & 46.98 & Graduated Measuring Cylinder (Muthuval et al., 1992) \\
\hline Soil Moisture (\%) & 21.05 & \\
\hline Water Holding Capacity & 47.12 & \\
\hline
\end{tabular}

Table.3 Chemical analysis of soil before sowing of Okra (Abelmoschus esculentus L.)

\begin{tabular}{|c|c|c|}
\hline Parameters & Method employed & results \\
\hline Soil pH (1:2) & Digital pH meter (Jackson 1958) & 7.3 \\
\hline Soil EC ( $\left(\mathrm{dS} \mathrm{m}^{-1}\right)$ & Digital conductivity meter (Wilcox 1950) & 0.27 \\
\hline Organic Carbon (\%) & Repid titration method (Walkley and Black, 1947) & 0.42 \\
\hline Available Nitrogen $\left(\mathrm{Kg} \mathrm{ha}^{-1}\right)$ & Alkaline permanganate method (Subbaih and Asija, 1956) & 276.43 \\
\hline Available Phosphorus (Kg ha $\left.{ }^{-1}\right)$ & Calorimetric Method (Olsen et al., 1954) & 16.51 \\
\hline Available Potassium $\left(\mathrm{Kg} \mathrm{ha}^{-1}\right)$ & Flame photometric method (Toth and Price, 1949) & 169.11 \\
\hline
\end{tabular}


Table.4 Effect of different levels of NPK and FYM on Physical parameters of soil in Okra

\begin{tabular}{|c|c|c|c|c|}
\hline Treatment & $\begin{array}{c}\text { Bulk } \\
\text { density }\left(\mathrm{Mg} \mathrm{m}^{-3}\right)\end{array}$ & $\begin{array}{c}\text { Particle } \\
\text { density }\left(\mathrm{Mg} \mathrm{m}^{-3}\right)\end{array}$ & $\begin{array}{c}\text { Pore } \\
\text { space }(\%)\end{array}$ & $\begin{array}{l}\text { Water holding } \\
\text { capacity \% }\end{array}$ \\
\hline $\mathbf{T}_{\mathbf{0}}$ & 1.31 & 2.62 & 47.15 & 45.53 \\
\hline $\mathbf{T}_{1}$ & 1.29 & 2.60 & 49.35 & 47.20 \\
\hline $\mathbf{T}_{2}$ & 1.28 & 2.59 & 50.09 & 53.24 \\
\hline $\mathbf{T}_{3}$ & 1.27 & 2.57 & 52.66 & 49.80 \\
\hline $\mathbf{T}_{4}$ & 1.25 & 2.56 & 55.31 & 54.27 \\
\hline $\mathbf{T}_{5}$ & 1.24 & 2.55 & 56.73 & 58.50 \\
\hline $\mathbf{T}_{6}$ & 1.26 & 2.52 & 57.73 & 55.68 \\
\hline $\mathbf{T}_{7}$ & 1.20 & 2.52 & 58.35 & 57.72 \\
\hline $\mathbf{T}_{8}$ & 1.18 & 2.50 & 60.1 & 63.63 \\
\hline F- test & NS & NS & $\mathrm{S}$ & $\mathrm{S}$ \\
\hline S. Em \pm & 0.01 & 0.00 & 0.13 & 0.34 \\
\hline C.D. at $5 \%$ & 0.02 & 0.01 & 0.38 & 1.03 \\
\hline
\end{tabular}

Table.5 Effect of different levels of NPK and FYM on Chemical parameters of soil in Okra

\begin{tabular}{|c|c|c|c|c|c|c|}
\hline Treatment & $\begin{array}{c}\text { pH (1:2) } \\
\text { w/v }\end{array}$ & $E C\left(d S ~ m^{-1}\right)$ & $\begin{array}{c}\text { Organic } \\
\text { carbon }(\%)\end{array}$ & $\begin{array}{l}\text { Nitrogen } \\
\left(\mathrm{kg} \mathrm{ha}^{-1}\right)\end{array}$ & 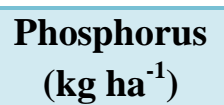 & $\begin{array}{c}\text { Potassium } \\
\left(\mathrm{kg} \mathrm{ha}^{-1}\right)\end{array}$ \\
\hline $\mathbf{T}_{0}$ & 7.26 & 0.28 & 0.39 & 216.50 & 14.69 & 131.14 \\
\hline $\mathbf{T}_{1}$ & 7.23 & 0.29 & 0.43 & 223.18 & 15.41 & 151.99 \\
\hline $\mathbf{T}_{2}$ & 7.09 & 0.30 & 0.47 & 232.48 & 16.67 & 173.20 \\
\hline $\mathbf{T}_{\mathbf{3}}$ & 7.07 & 0.30 & 0.45 & 236.76 & 15.76 & 154.29 \\
\hline $\mathbf{T}_{4}$ & 7.01 & 0.31 & 0.48 & 247.39 & 17.31 & 171.84 \\
\hline $\mathbf{T}_{5}$ & 7.00 & 0.31 & 0.56 & 260.72 & 21.83 & 186.31 \\
\hline$T_{6}$ & 6.98 & 0.32 & 0.49 & 277.73 & 19.68 & 163.51 \\
\hline $\mathbf{T}_{7}$ & 6.97 & 0.32 & 0.54 & 284.26 & 23.37 & 182.38 \\
\hline $\mathbf{T}_{8}$ & 6.88 & 0.33 & 0.62 & 297.56 & 26.35 & 202.55 \\
\hline F - test & $\mathrm{S}$ & $\mathrm{S}$ & $\mathrm{S}$ & $\mathrm{S}$ & $\mathrm{S}$ & $\mathrm{S}$ \\
\hline S. Em \pm & 0.01 & 0.13 & 0.01 & 0.40 & 0.31 & 0.35 \\
\hline C.D. at $5 \%$ & 0.02 & 0.40 & 0.02 & 1.20 & 0.93 & 1.06 \\
\hline
\end{tabular}

Fig.1 Effect of different levels of NPK and FYM on Physical parameters of soil in Okra

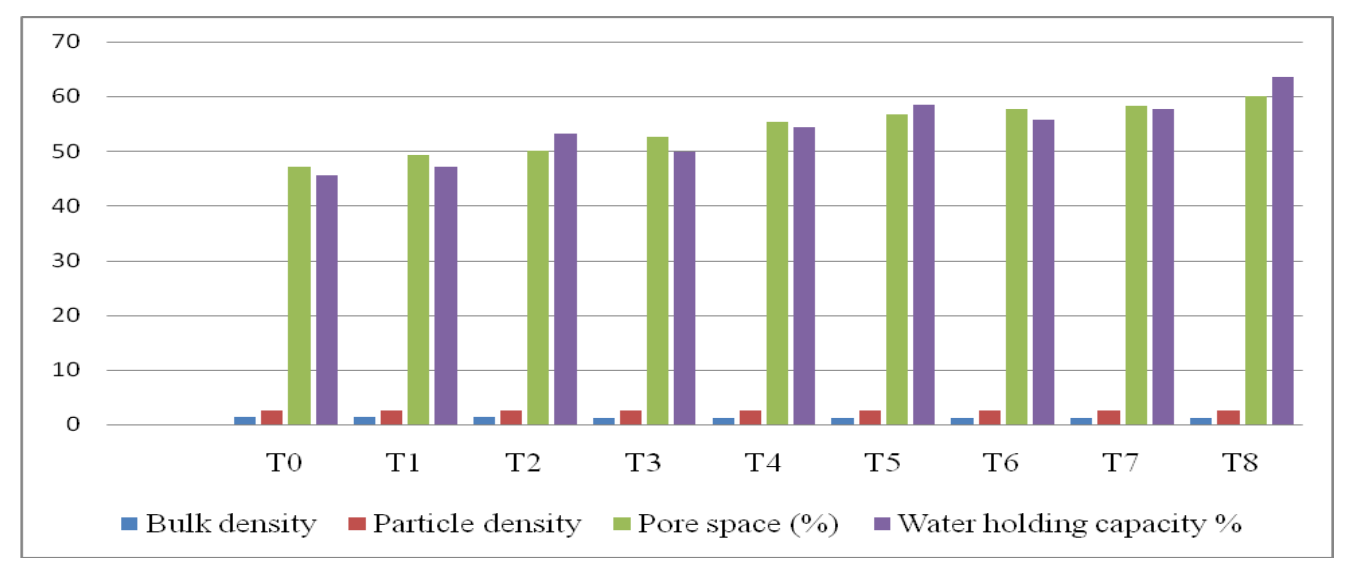


Fig.2 Effect of different levels of NPK and FYM on Chemical parameters of soil in Okra

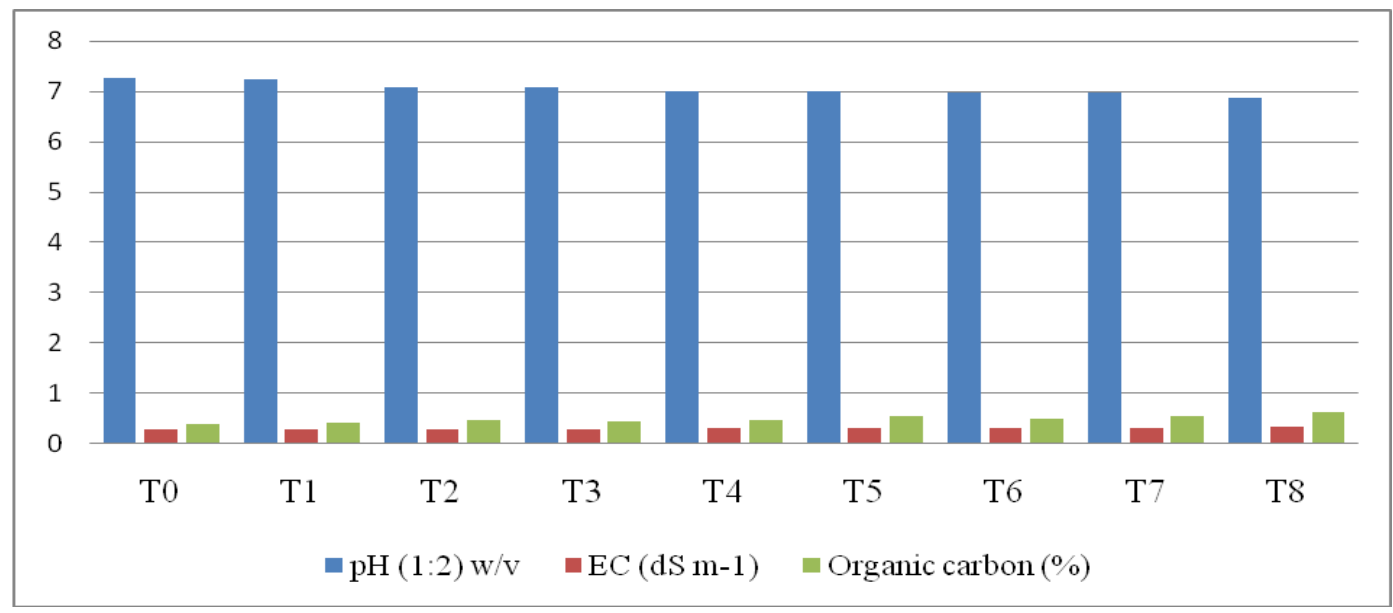

Fig.3 Effect of different levels of NPK and FYM on chemical parameters of soil in Okra

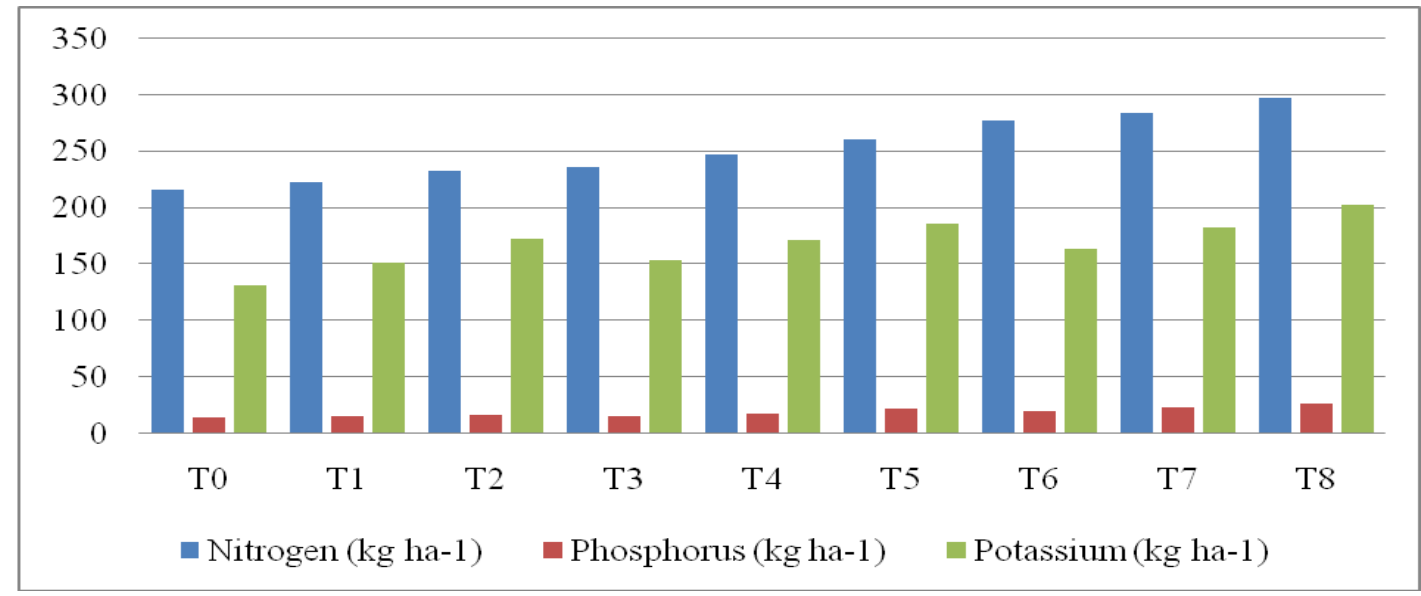

\section{Available Nitrogen $\left(\mathrm{Kg} \mathrm{ha}^{-1}\right)$}

The data presented in shows the available nitrogen in soil as influenced by $\mathrm{N} P \mathrm{~K}$ fertilizers and FYM. The available nitrogen in soil increased significantly with the increase in levels of N P K and FYM. The maximum available nitrogen in soil was recorded 297.56 $\left(\mathrm{Kg} \mathrm{ha}^{-1}\right)$ in treatment $\mathrm{T}_{8}\left(100 \% \mathrm{RDF} @ \mathrm{~N}_{100}\right.$ $\mathrm{P}_{60} \mathrm{~K}_{50} \mathrm{~kg} \mathrm{ha} \mathrm{ha}^{-1}+100 \%$ FYM @ $25 \mathrm{t} \mathrm{ha}^{-1}$ ) which was significantly higher than any other treatment combination and the minimum available nitrogen in soil was recorded 216.50 $\left(\mathrm{Kg} \mathrm{ha}^{-1}\right)$ in treatment $\mathrm{T}_{0}$ (control). Similar results were observed by Bhambhu et al. (2016).

\section{Available Phosphorus (Kg ha $\left.{ }^{-1}\right)$}

The data presented in shows the available phosphorus in soil as influenced by $\mathrm{N} \mathrm{P} \mathrm{K}$ fertilizers and FYM. The available phosphorus in soil increased significantly with the increase in levels of N P K and FYM. The maximum available phosphorus in soil was recorded $26.35\left(\mathrm{Kg} \mathrm{ha}^{-1}\right)$ in treatment $\mathrm{T}_{8}$ (100\% RDF@ @ $\mathrm{N}_{100} \mathrm{P}_{60} \mathrm{~K}_{50} \mathrm{~kg} \mathrm{ha}{ }^{-1}+100 \%$ FYM @ $25 \mathrm{t} \mathrm{ha}^{-1}$ ) which was significantly higher than any other treatment combination and the minimum available phosphorus in soil was recorded $14.69\left(\mathrm{Kg} \mathrm{ha}^{-1}\right)$ in treatment $\mathrm{T}_{0}$ (control). Similar results were observed by Yadav et al. (2019). 


\section{Available Potassium (Kg ha $\left.{ }^{-1}\right)$}

The data presented in shows the available potassium in soil as influenced by $\mathrm{N} \mathrm{P} \mathrm{K}$ fertilizers and FYM. The maximum available potassium in soil was recorded 202.55 ( $\mathrm{Kg}^{-}$ $\left.{ }^{1}\right)$ in treatment $\mathrm{T}_{8}\left(100 \% \mathrm{RDF} @ \mathrm{~N}_{100} \mathrm{P}_{60} \mathrm{~K}_{50}\right.$ $\mathrm{kg} \mathrm{ha}^{-1}+100 \%$ FYM @ $25 \mathrm{t} \mathrm{ha}^{-1}$ ) which was significantly higher than any other treatment combination and the minimum available potassium in soil was recorded 131.14 (Kg ha ${ }^{1}$ ) in treatment $\mathrm{T}_{0}$ (control). Similar results were observed by Bhambhu et al. (2016).

It was concluded from trial that the different levels of N P K and FYM used for okra, the treatment combination $\mathrm{T}_{8}-[100 \%$ N P K @ $\mathrm{N}_{100} \mathrm{P}_{60} \mathrm{~K}_{50} \mathrm{~kg} \mathrm{ha}^{-1}+100 \%$ FYM @ $25 \mathrm{t} \mathrm{ha}^{-1}$ ] was found to be the best treatment physicochemical properties of soil. The slight decrease in soil $\mathrm{pH} 6.8$, bulk density $1.18 \mathrm{Mg}$ $\mathrm{m}^{-3}$ and particle density $2.50 \mathrm{Mg} \mathrm{m}^{-3}$ has resulted due to the application of $\mathrm{T}_{8} @ 100 \%$ RDF @ $\mathrm{N}_{100} \mathrm{P}_{60} \mathrm{~K}_{50} \mathrm{~kg} \mathrm{ha}^{-1}+@ 100 \%$ FYM @ $25 \mathrm{t} \mathrm{ha}^{-1}$ ). While maximum pore space 60.1 $\%$, water holding capacity $63.63 \%$, organic carbon $0.62 \%$, available nitrogen $297.56 \mathrm{~kg}$ $\mathrm{ha}^{-1}$, available phosphorus $26.35 \mathrm{~kg} \mathrm{ha}^{-1}$ and available potassium $202.55 \mathrm{~kg} \mathrm{ha}^{-1}$, found with application of $\mathrm{T}_{8} @ 100 \%$ RDF @ $\mathrm{N}_{100}$ $\mathrm{P}_{60} \mathrm{~K}_{50} \mathrm{~kg} \mathrm{ha}^{-1}+$ @100\% FYM @ $25 \mathrm{t} \mathrm{ha}^{-1}$ ). It was also revealed that the application of NPK with FYM were excellent source for fertilization than fertilizers alone. It can be concluded that combined application of FYM and inorganic NPK fertilizers improved the physico-chemical properties of soil.

\section{Acknowledgements}

I am grateful for ever-inspiring guidance, constant encouragement, keen interest and scholarly comments and constructive suggestions throughout the course of my studies and investigation, from, head of the department and staff, department of soil science and agricultural chemistry, sam higginbottom university of agriculture, technology and sciences, Prayagraj, Uttar Pradesh.

\section{References}

Abou El-Magd, M. M., El-Bassiony, A. M. and Fawzy, Z. F. (2006) Effect of organic manure with or without chemical fertilizers on growth, yield and quality of some varieties of broccoli plants. Journal of Applied Sciences Research. 2: 791-798.

Agbede, T. M. and Adekiya, A. O. (2012) Effect of wood ash, poultry manure and NPK fertilizer on soil and leaf nutrient composition, growth and yield of okra (Abelmoschus esculentus). Emir. $J$. Food Agric. 2012.24 (4): 314-321.

Akande, M. O., Oluwatoyinbo, F. I., Adediran, J. A., Buari, K. W. and Yusuf, I. O. (2003) Soil amendments affect the release of $\mathrm{P}$ from rock phosphate and the development and yield of okra. $J$ of Veg. Crop Production,9(2):3-9.

Bhambhu, Ram, Krishan., Thomas, Tarence and Rao P. Smriti (2016) Effect of NPK and Neem Cake on PhysicoChemical Properties of Soil, Growth and Yield of Hybrid maize (Zea mays L.). Advances in Life Sciences 5(16).

Bhattacharyya, R., Chandra, S., Singh, R., Kundu, S., Srivastva, A. and Gupta, H. (2007) Long-term farm yard manure application effects on properties of a silty clay loam soil under irrigated wheat-soybean rotation. Soil Till. Res. 94, 386-396.

Bhende, S. K., Deshmukh, H. K., Nimbolkar, P.K., Dewangan, R. K. and Nagone, A. H. (2015) Effact of phosphorus and potassium on quality attributes of okra cv. 'Arka Anamik'. Int. J. Environ Sci. 6(2) 225-231. 
Bouyoucous, G. J. (1927) The hydrometer as a new method for the mechanical analysis of soils.Soil Sci., 23: 393-395.

Chattopadhyay, A., Dutta, S. and Chatterjee, S. (2011) Seed yield and quality of okra as influenced by sowing dates. African Journal of Biotechnology 10(28): 54615467.

Das, A. K., Prasad, B. and Singh, R. (2014) Response of chemical fertilizer and vermicompost on okra (Abelmoschus esculentus L.) cv. Prabhani kranti. The Asian J. of Horti. 9(2):372- 376.

FAO. (2018) The state of food and agriculture (Food and Agriculture Organization of the United Nations. 2018).

Firoz, Z. A. (2009) Impact of nitrogen and phosphorus on the growth and yield of okra [Abelmoschus esculentus (L.) Moench] in hill slope condition. Bangladesh J. Agril. Res. 34(4): 713722, December 2009.

Gemede, H.F., Ratta, N., Haki, G.D., Woldegiorgis, A.Z., Beyene, F., (2014) Nutritional quality and health benefits of okra (Abelmoschus esculentus): a review. Food Sci. Qual. Manage. 33, 87-96.

Habtamu, F. G., Negussie, R., Gulelat, D.H., Ashagrie, Z. W. and Fekadu, B. (2014) Nutritional quality and health benefits of okra (Abelmoschus esculentus). Food Science and Quality Management, 33: ISSN 2224-6088.

Jackson, M. L. (1958) Soil chemical analysis, Second edition Indian Reprint, prentice hall of India, New Delhi. PP 498.

Kaur, K., Kapoor, K. K. and Gupta, A. P. (2005) Impact of organic manure with and without mineral fertilizers on soil chemical and biological properties under tropical conditions. Journal Nutri. Soil Sci, 168:117-122.

Lakra, Reena., Swaroop, Narendra and Thomas, Tarence (2017) Effect of Different Levels of NPK and
Vermicompost on Physico-Chemical Properties of Soil, Growth and Yield of Okra [Abelmoschus esculentus L.] var. Rohini. International Journal of Current Microbiology and Applied Sciences. (2017) 6(7): 1398-1406.

Mal, B., Mahapatra, P., Mohanty S. and Mishra H. N. (2013) Growth and yield parameters of okra (Abelmoschus esculentus) influenced by Diazotrophs and chemical fertilizers. Journal of Crop and Weed, 9(2):109-112(2013).

Muthuval, P., Udayasoorian, C., Nateson, R. and Ramaswami, P.P. (1992) Elucidated the Laboratory manual on soil analysis for physical and chemical characteristic of soil, Introduction to soil analysis. Laser typesetting and offset printing by scroll DP, 68, D. B. Road, R. S. Puram, Coimbatore 641002.

Naveed, A., Khan, A.A., \& Khan, I.A, (2009). Generation mean analysis of water stress tolerance in okra (Abelmoschus esculentus L.). Pak. J. Bot., 41: 195205.

NHB. (2018- 19) National Horticulture Database - 2017-18. National Horticulture Board Government of India, Gurgaon, India. www.nhb.gov.in.

Ola, Rajendra., David, A. Alfred., Thomas, Tarence., Baloda, Satyapal Singh., and Singh, Prabhoo (2017) Response of Different Levels of N P K and FYM on Soil Health and Yield of Okra (Abelmoschus Esculentus L.) Var. Arka Anamika. Chem Sci Rev Lett 2017, 6(22), 827-831.

Olsen, S. R., Cole, C. V., Watnahe, F. S. and Dean, L. A. (1954) Estimation of available phosphorus in soils by extraction with sodium bicarbonate U.S. Deptt. Agr.Circ. pp 939.

Ray, R., Patra, S.K., Ghosh, K. K. and Sahoo, S.K. (2005) Integrated Nutrient Management in okra [Abelmoschus 
esculentus (L.) Moench] in a River Basin. Indian Journal of Horticulture. 62(3): 260-264.

Salvi, V. G., Shinde, Minal, Bhure, S. S. and Khanvilkar, M. H. (2015) Effect of integrated nutrient management on soil fertility and yield of okra in coastal region of Maharashtra. Asian J. Soil Sci., (Dec., 2015) 10 (2): 201-209.

Sathish, D., and Eswar, A. (2013). A Review on: Abelmoschus esculentus (Okra). Int. Res J Pharm. App Sci., 2013; 3(4):129-132.

Solangi, Majeeduddin., Tagar, Ahmed, Ali., Solangi, Abdul, Malik., Siyal, Abdul, Ghafoor., Soothar, Rajesh, Kumar and Shah, Ali, Raza. (2015) Nutrient uptake of some Okra varieties as influenced by different levels of applied N, P and K. Sci. Int. (Lahore), 27(5), 4327-4331.

Subbiah, B. V. and Asija, G. L. (1956) a rapid procedure for the estimate of Available nitrogen in soil current sciences.25:259-260.

Tadesse, T., Dechassa. N., Bayu, W. and Gebeyehu, S. (2013) Effects of Farmyard Manure and Inorganic Fertilizer Application on Soil PhysicoChemical Properties and Nutrient Balance in Rain-Fed Lowland Rice Ecosystem. American Journal of Plant
Sciences, 4: 309-316.

Toth, S. J. and Prince, A. L. (1949). Estimation of Cation Exchange Capacity and exchangeable $\mathrm{Ca}, \mathrm{K}$, and $\mathrm{Na}$ content of soil by flame photometer technique. Soil Sci. 67: 439-445.

Uka, U. N., Chukwuka, K. S. and Iwuagwu, M. (2013) Relative Effect of Organic and Inorganic Fertilizers on the Growth of Okra [Abelmoschus esculentus (l.) moench]. Journal of Agricultural Sciences Vol. 58, No. 3, 2013 Pages 159-166.

Walkley, A. and Black, I. A. (1947) Critical examination of rapid method for determining organic carbon in soils, effect of variance in digestion conditions and of inorganic soil constituents. Soil sci. pp. 632:251.

Wilcox, L. V. (1950) Electrical conductivity, Amer Water works Assoc. J. 42: pp 775-776.

Yadav, Sanwar Mal., Yadav, Lekhraj., Rao, P. Smrit and Thomas, Tarence (2019) Effect of different levels of NPK and Vermicompost on Physico-Chemical properties of Soil of okra (Abelmoschus esculentus L.) Var. Kashi Kranti. International Journal of Chemical Studies 2019; 7(5): 31-34.

\section{How to cite this article:}

Radhakishan Yadav, Tarence Thomas and Narendra Swaroop. 2020. Effect of Different Levels of NPK and FYM on Physico-Chemical Properties of Soil of Okra [Abelmoschus esculentus L.] Var. Parbhani Kranti. Int.J.Curr.Microbiol.App.Sci. 9(08): 603-612. doi: https://doi.org/10.20546/ijcmas.2020.908.067 